\title{
PREDNISOLONE VERSUS PREDNISOLONE COMBINED WITH ACYCLOVIR FOR THE TREATMENT OF BELL'S PALSY: A COMPARATIVE STUDY IN PERIPHERAL REFERRAL CENTRE
}

\author{
Shrestha $K^{1^{*}}$, Shah $R K^{2}$, Sapkota $S^{3}$, Giri $^{3}$
}

\section{Affiliation}

1. Consultant, Department of Otorhinolaryngology, Birat Medical College and Teaching Hospital, Nepal.

2. Assistant Professor, Department of Otorhinolaryngology, Birat Medical College and Teaching Hospital, Nepal.

3. Lecturer, Department of Otorhinolaryngology, Birat Medical College and Teaching Hospital, Nepal.

\section{ARTICLE INFO}

Article History

Received : 06July, 2018

Accepted : 12 August, 2018

Published : 31 August, 2018

(c) Authors retain copyright and grant the journal right of first publication with the work simultaneously licensed under Creative Commons Attribution License CC - BY 4.0 that allows others to share the work with an acknowledgment of the work's authorship and initial publication in this journal.

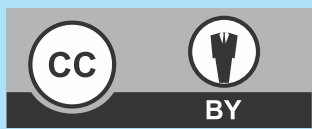

\section{ORA 72}

DOI: $\underline{\text { http://dx.doi.org/10.3126/bjhs.v3i2.20942 }}$

* Corresponding Author

Dr Karuna Shrestha

Consultant Otorhinolaryngologist

Department of Otorhinolaryngology

Birat Medical College and Teaching Hospital

Email: karunashrestha215@gmail.com ORCID: https://orcid.org/0000-0002-6332-9095

\section{Citation}

Shrestha K, Shah RK, Sapkota S, Giri S. Prednisolone Verses Prednisolone Combined with Acyclovir for the Treatment of Bell's Palsy A Comparative Study in Peripheral Referral Centre. BJHS 2018;3(2)6: 443-446

\section{ABSTRACT \\ Introduction}

Bell's palsy is an idiopathic facial nerve palsy of sudden onset, usually, unilateral. Recent evidence suggests association of Herpes simplex infection with Bell's palsy but exact cause is unknown. Prednisolone are widely used in the treatment of Bell's palsy. However, the efficacy of additional treatment with acyclovir is uncertain.

\section{Objective}

To evaluate whether a prednisolone with acyclovir provide a better degree of facial muscle recovery outcomes than prednisolone alone in patient with Bell's palsy.

\section{Methodology}

This is a hospital based longitudinal cross sectional study conducted in Birat Medical College and Teaching Hospital and Birat Hospital PVT LTD, Biratnagar, Nepal from January 2017 to May 2018. A total of 42 patient diagnosed with Bell's palsy are included in this study, where 21 patient are treated with prednisolone and remaining 21 patient treated with a combination of prednisolone and acyclovir. The House-Brackmann grading scale is used for recording the initial presentation of patient with Bell's palsy and their early recovery on follow-up visit. The collected data was analysed using SPSS 18.0 .

\section{Results}

The total number of patients included in this study was 42 . Mean age of patients is $27.1 \pm 10$ years. Among them 25 (59.5\%) were male and $17(40.5 \%)$ were female where male and female ratio is 1.5:1. Prednisolone plus acyclovir given in combination in Bell's palsy patients has as $76.2 \%$ recovery while prednisolone given alone has a $57.1 \%$ recovery $P$ value $<0.195$, odds ratio 2.400 ( $95 \%$ confidence interval $0.638-$ 9.028).

\section{Conclusions}

Prednisolone and acyclovir, the combined therapy is effective than prednisolone alone in the treatment of Bell's palsy. It requires confirmation with randomized controlled trial.

\section{KEYWORDS}

Acyclovir, bell's palsy, prednisolone 


\section{INTRODUCTION}

Bell's palsy is named after the British physician Sir Charles Bell, who described the onset, physical findings, and course of the disease in $1821 .{ }^{1}$ The incidence rate of 20 per 100,000 per year and equal in both genders. Bell's palsy can occur at any age but the median age is 40 and both sides may be affected equally. ${ }^{2}$ Bell's palsy is defined as an idiopathic, sudden onset peripheral facial nerve palsy.

The exact causes of Bell's palsy remains unclear, although ischaemic neuropathy, viral infection usually herpes simplex virus, and autoimmune disorders like sarcoidosis are proposed as a causes of Bell's palsy. ${ }^{4}$

The pathophysiology of Bell's palsy involves inflammation and compression of seventh cranial nerve around the area where it exists the skull via stylomastoid foramen. The facial nerve travels through the fallopian canal and then enters the parotid gland where it divides into five terminal branches that are responsible for innervating the muscles of facial expression.The oedema and inability to expand beyond the inelastic bony fallopian canal leads to pressure effect and demyelination of axon, resulting in weakness or paralysis of everything that it innervates.

Many viruses including Herpes simplex virus type 1 (HSV-1), Herpes simplex virus type 2 (HSV-2), Human herpes virus, Varicella zoster virus (VZV), Adeno virus, influenza B virus, Coxsackie virus and Epstein-Barr virus (EBV) have been linked to the development of Bell's palsy but it is believed that HSV-1 is the one that is responsible for idiopathic facial palsy. ${ }^{6} \mathrm{HSV}$ may remains latent at the geniculate ganglia and increasing evidence implies that Bell's palsy is caused by the latent HSV being reactivated from the cranial nerve ganglion and causes inflammation of facial nerve., ${ }^{7,9,9}$

The majority of patients with Bell's palsy recover completely without intervention. Complete recovery typically occur within 6 months. Approximately 30\% of patients do not recover completely and gets residual symptoms such as contracture, synkinesis and paresis. ${ }^{10}$

Due to its unknown etiology, treatment of Bell's palsy remains controversial, frequently debated and variable. Steroid and antiviral are main two types of pharmacological treatment that have been used for Bell's palsy. ${ }^{3}$ The rational for these treatment is based on the presumed pathophysiology of Bell's palsy, the use of steroids to counteract the inflammatory process and antivirals is aimed at eradication of virus such as HSV-1, antiviral therapy seems logical. ${ }^{4,11}$

Most surgeon would advocate a combination of steroid and antiviral drugs. The usual recommended regime is oral prednisolone $1 \mathrm{mg} \backslash \mathrm{kg} \backslash$ day for 7 days followed by ten days taper and oral acyclovir 200-400mg 5 times daily for 7 days.

\section{METHODOLOGY}

This is a hospital based longitudinal cross sectional study. A total of 42 patient diagnosed with Bell's palsy who visited OPD of Otorhinolaryngology of Birat Medical College and Teaching Hospital and Birat Hospital PVT LTD, Biratnagar, Nepal from January 2017 to May 2018 are included in this study. The permission to conduct this study was taken from the institution. All patient with Bell's palsy age of more than 10 years and of either sex were enrolled in the study.
All patients were randomly divided into two group. The first Group A of 21 patient were treated with prednisolone and remaining Group B of 21 patient were treated with a combination of prednisolone and acyclovir. In Group A oral prednisolone $1 \mathrm{mg} \backslash \mathrm{kg} \backslash$ day was given for 7 days followed by ten days taper and Group B were treated with a combination of oral prednisolone $1 \mathrm{mg} \backslash \mathrm{kg} \backslash$ day and oral acyclovir $400 \mathrm{mg}$ five times per day for 7 days.

Patient with facial palsy due to Ramsey Hunt syndrome, chronic suppurative otitis media, systemic infection, vasculopathy, secondary causes of $7^{\text {th }}$ nerve palsy, sensitivity to acyclovir, Bell's palsy with $>3$ days of symptom onset, other cranial nerve paralysis, patients who are lost to follow up are excluded.

The House-Brackmann grading scale was used for recording the initial presentation of patient with Bell's palsy and their recovery on follow-up visit. ${ }^{12}$ Follow-up was done after 7 days, 14 days and at the end of first month. Based on the House-Brackmann criteria, complete recovery is grade 1 , no response grade 6 and partial facial muscle recovery defined at least as grade 2 .

This is therefore the comparative study on recovery outcomes in patients with Bell's palsy treated either with prednisolone alone or with a combination of prednisolone and acyclovir.

\section{RESULT}

The total number of patients included in this study was 42 . Mean age of patients is $27.1 \pm 10$ years. Highest proportion of patients were of age group $41-50$ years (33.3\%), followed by $10-20$ years $(26.2 \%), 21-30$ years $(21.4 \%), 31-40$ years (16.7\%) and 51-60 years (2.4\%). Among them 25 (59.5\%) were male and $17(40.5 \%)$ were female where male and female ratio is 1.5:1. Prednisolone plus acyclovir given in combination in Bell's palsy patients has as $76.2 \%$ recovery while prednisolone given alone has a $57.1 \%$ recovery $P$ value $<0.195$, odds ratio 2.400 (95\% confidence interval $0.638-$

Table 1: Age wise distribution among study population with Bell's palsy

$\begin{array}{lcc}\text { Age distribution } & \begin{array}{c}\text { Number of } \\ \text { patients }\end{array} & \text { Percent } \\ \text { 10-20 years } & 11 & 26.2 \\ \text { 21-30 years } & 9 & 21.4 \\ \text { 31-40 years } & 7 & 16.7 \\ \text { 41-50 years } & 14 & 33.3 \\ \text { 51-60 years } & 1 & 2.4\end{array}$

Table 2: Gender distribution among study population with Bell's palsy

$\begin{array}{lcc}\text { Gender } & \begin{array}{c}\text { Number of } \\ \text { patients }\end{array} & \text { Percent } \\ \text { Male } & 25 & 59.5 \\ \text { Female } & 17 & 40.5\end{array}$


Table 3: Grading of severity of Bell's palsy based on House-brackman scale among study population

\section{House-brackmann scale}

gradellI(moderate dysfunction)

gradelV(moderately severe dysfunction)

gradeV(severe dysfunction)

Table 4: Recovery pattern following prednisolone (Group A) and combined prednisolone with acyclovir (Group B) intake in patients having Bell's palsy

$\begin{array}{llll} & \text { Group A } & \text { Group B } & \text { P - Value } \\ \text { Complete } & 12(57.1 \%) & 16(76.2 \%) & \\ \text { Partial } & 9(42.9 \%) & 5(23.8 \%) & <0.195 \\ \text { No response } & 0(0 \%) & 0(0 \%) & \end{array}$

\section{DISCUSSION}

Viral etiology is the most likely cause of Bell's palsy, numerous studies have identified Herpes simplex virus (HSV 1) as the causative agent, and it has been found in patients who have undergone decompression for Bell's palsy. ${ }^{10}$ Reactivation of latent HSV from the cranial nerve ganglion causes inflammation of facial nerve. ${ }^{7,8,9}$ Murakami et al in 1996 explored the link between HSV and Bell's palsy. Viral genomes of HSV 1 were analyzed in clinical samples of facial nerve endoneurial fluid using polymerase chain reaction (PCR). HSV 1 genomes were detected in 11 of 14 patients (79\%) with Bell's palsy. ${ }^{13}$ HSV-1 has been detected on fresh and stored geniculate ganglions of temporal bone on polymerase chain reaction (PCR) assays. ${ }^{14,15,16}$

The treatment of the patients with Bell's palsy depends on a number of variables. Steroid treatment has been shown to be effective in many studies of patient with Bell's palsy. ${ }^{17,18}$ However adding antiviral drugs to the treatment of Bell's palsy is to eradicate the virus while steroid reduced swelling and inflammation of nerve. ${ }^{19}$ Use of an antiviral agent in addition to steroid in the treatment of Bell's palsy has been shown to improve the recovery of facial function when compared to corticosteroid treatment alone. ${ }^{20,21}$

Kawagachi et al. showed that the recovery rate in patients with combination of prednisolone and valacyclovir were significantly greater than prednisolone alone. ${ }^{7}$ de Almeida $J R$ et al suggested that combination of antiviral and glucocorticoid treatment reduced risk of unfavourable recovery as compared with glucocorticoid treatment alone. $^{22}$ Lockhart $\mathrm{P}$ et al showed that treatment with antiviral agents alone were unsatisfactory, while the combination of corticosteroid and acyclovir therapy were significantly better. ${ }^{20}$ Hato et al study, which reported a significant benefit of adding valaciclovir and showed that the benefit of valaciclovir was greater in patients with severe facial paralysis at presentation than in those with moderate paralysis. ${ }^{23}$ Minnerop et al performed a subgroup analysis of patients who presented with severe facial muscle paralysis (House-Brackmann grade of 5 or 6 ) and found significantly better recovery in patients who received famciclovir plus steroids than in those on steroids alone (72\% v 47\%, respectively, achieved normal function. ${ }^{24}$

In a double blind, placebo-controlled, randomized study, early treatment with prednisolone significantly improved Bell's palsy. However, no significant advantage was found for acyclovir alone or in combination with prednisolone. ${ }^{25}$ Steroids are effective in patients whose Bell's palsy is started recently, and that antiviral therapy does not significantly improved the facial nerve function. ${ }^{26}$ The recovery rate with combination therapy increases only slightly as compared to treating with prednisolone alone, according to Numthavaj et al Prednisolone is the basis of Bell's palsy treatment. ${ }^{27}$

On the other hand, one of the most recently published trials, by Engstrom et al, is in opposition to this argument. Patients in this trial had a median House-Brackmann grade of 4 at presentation, and the authors convincingly showed no benefit of adding valaciclovir to steroids. ${ }^{28}$

However, other studies that underestimate the efficacy of treatment by adding acyclovir. In our study though the response seems to be better with combined acyclovir and the prednisolone over prednisolone alone, the difference was found to be statistically insignificant.

\section{CONCLUSION}

The combination therapy of prednisolone along with acyclovir is found to be better than prednisolone alone yet statistically insignificant. For the confirmation of the finding we recommend a randomized controlled trial with larger sample size.

\section{RECOMMENDATION}

The study recommends the combined therapy of prednisolone and acyclovir as the effective treatment for Bell's palsy.

\section{LIMITATION OF THE STUDY}

In this study sample size was small therefore multicentre studies with large sample size are required.

\section{ACKNOWLEDGEMENT}

I would like to thanks all the faculty from department of Otorhinolaryngology of Birat Medical College and Teaching Hospital and others who are involved directly and indirectly to make this study a success and also the entire patients who were enrolled in this study.

\section{CONFLICT OF INTEREST}

None

\section{FINANCIAL DISCLOSURE}

None 


\section{REFERENCES}

1. Bird TD, Nicolaus A. Friedrich's description of peripheral facial nerve paralysis in 1798. J Neural Neurosurg Psychiatry 1979; 42: 56-8. PMID: 368292.

2. Rowlands S, Hooper R, Hughes R, Burney P. The epidemiology and treatment of Bell's palsy in the UK. Eur J Neurol 2002; 9: 63-7. PMID: 11784378.

3. Gilden DH. Bell's palsy. N Engl J Med 2004; 351: 1323-31. PMID: 15385659.

4. John K, Goudakos JK, Markou KD, et al. Corticosteroids vs Corticosteroids Plus Antiviral Agents in the Treatment of Bell Palsy. Arch Otolaryngol Head Neck Surg. 2009;135(6):558-564. PMID: 19528403.

5. Jackson CG, Von Doersten PG. The facial nerve: Current trends in diagnosis, treatment, and rehabilitation. Med Clin North Am. 1999; 83:179-195. PMID: 9927969.

6. Rodrigues de Araujo M, Rodrigues Azenha M, Capelari MM, et al. Management of Bell's Palsy: A Report of 2 Cases. jcda. 2008;74(9):823.

7. Kawaguchi K, Inamura H, Abe Y, Koshu H, Takashita E, Muraki Y, et al. Reactivation of herpes simplex virus type 1 and varicella-zoster virus and therapeutic effects of combination therapy with prednisolone and valacyclovir in patients with Bell's palsy. Laryngoscope 2007;117: 147-56. PMID: 17202945.

8. Stjernquist-Desatnik A, Skoog E, Aurelius E. Detection of herpes simplex and varicella zoster viruses in patients with Bell's palsy by the polymerase chain reaction technique. Ann OtolRhinolLaryngol 2006; 115: 306-11. PMID: 16676828.

9. Linder T, Bassart W, Bodmer D. Bell's palsy and herpes simplex virus: fact or mystery. OtolNeurotol 2005; 26: 109-13.

10. Peitersen E. The natural history of Bell's palsy. Am J Otol 1982;4:10711. PMID: 7148998.

11. Holland NJ, Weiner GM. Recent developments in Bell's palsy. BMJ. 2004;329(7465):553-557. PMID: 15345630.

12. House JW, Brackmann DE. Facial nerve grading system. Otolaryngol. Head Neck Surg 1985; 93: 146-147. PMID: 3921901.

13. Murakami S, Mizobuchi M, Nakashiro Y, Doi T, Hato N, Yanagihara N. Bell's palsy and herpes simplex virus: identification of viral DNA in endoneurial fluid and muscle. Ann intern Med 1996; 124: 27-30. PMID: 7503474

14. Carreno $M$, et al. Amplification of herpex simplex virus type 1 DNA in human geniculate ganglia from formalin-fixed, non-embedded temporal bones. Otolaryngol Head Neck Surg 2000;123:508-11.

15. Burgess MD, Michaels L, Bale JF Jr, Smith RJ. Polymerase chain reaction amplification of herpes simplex viral DNA from the geniculate ganglia of a patient with Bell's palsy. Ann OtolRhinolLaryngol 1994;103:775-9. doi.org/10.1177/000348949410301006
16. Takasu T, furuta $\mathrm{Y}$, Sato KK, et al. Detection of latent herpes simplex virus DNA and RNA in human geniculate ganglia by the polymerase chain reaction. ActaOtolaryngol (Stockh) 1992;112:1004-11.

17. Berg T, Bylund N, Marsk E et al. The effect of prednisolone on sequelae in Bell's palsy. Arch Otolaryngol Head Neck Surg 2012; 138: 445-9. PMID: 22652942

18. Salinas RA, Alvarez G, Daly F, Ferreira J. corticosteroids of Bell's palsy (idiopathic facial paralysis). Cochrane Database Syst Rev 2010; CD001942. PMID: 20238317.

19. Lockhart P, Daly F, Pitkethly M, et al. Antiviral treatment for Bell's palsy (idiopathic facial paralysis). Cochrane Database Syst Rev 2009; (4):CD001869. PMID: 19821283.

20. Adour KK, Rubovianes JM, Von Doersten PG,Byl FM. Bell's palsy treatment with acyclovir and prednisone compared with prednisone alone: a double- blind, randomized, controlled trial. Ann OtolRhinolLaryngol 1996;105:371-8. PMID: 8651631.

21. Lee HY, Byun JY, Park MS, Yeo SG. Steroid-antiviral treatment improves the recovery rate in patients with severe Bell's palsy. Am J Med 2013; 126: 336-41. PMID: 23394867.

22. de Almeida JR, Al Khabori M, Guyatt GH, Witterick IJ, Lin VY, Nedzelski $\mathrm{JM}$, et al. Combined corticosteroid and antiviral treatment for Bell palsy: a systematic review and meta-analysis. JAMA 2009; 302: 98593. PMID: 19724046

23. Hato N, Yamada H, Kohno H, Matsumoto S, Honda N, Gyo K, et al. Valacyclovir and prednisolone treatment for Bell's palsy: a multicenter, randomized, placebo-controlled study. OtolNeurotol 2007;28:408-13. PMID: 17414047.

24. Minnerop M, Herbst M, Fimmers R, Matz B, Klockgether T, Wullner U. Bell's palsy: Combined treatment of famciclovir and prednisone is superior to prednisone alone. J Neurol2008;255:1726-30. PMID: 18769863.

25. Sullivan FM, Swan IRC, Donnan PT, et al. Early Treatment with Prednisolone or Acyclovir in Bell's palsy. N Engl J Med. 2007;357:1598-1607. PMID: 17942873.

26. Gronseth GS, Paduga R. Evidence-based guideline update: steroids and antivirals for Bell palsy: report of the Guideline Development Subcommittee of the American Academy of Neurology. American Academy of Neurology. 2012;79(22):2209-13. PMID: 23136264.

27. Numthavaj $P$, Thakkinstian A, Dejthevaporn $\mathrm{CH}$, et al. Corticosteroid and antiviral therapy for Bell's palsy: A network meta-analysis. BMC Neurology. 2011;11:1. PMID: 21208452

28. Engstrom M, Berg T, Stjernquist-Desatnik A, Axelsson S, Pitkaranta A, Hultcrantz $M$, et al. Prednisolone and valaciclovir in Bell's palsy: a randomised, double-blind, placebo-controlled, multicentre trial. Lancet Neurol 2008;7:993-1000. DOI: 10.1016/S1474-4422(08)70221-7 